\title{
Constraints and Challenges Faced by Women Entrepreneurs in Emerging Market Economy and the Way Forward
}

\author{
Reena Agrawal ${ }^{1}$ \\ Jaipuria Institute of Management, Lucknow, India
}

\section{A B S T R A C T}

It is well acknowledged fact that entrepreneurship is an engine of economic growth and social development. Women entrepreneurship though has been growing around the world, but the evidences suggest that women entrepreneurs continue to be adversely affected by the numerous socio-economic issues in the male dominated business societies, which hugely undermine the morale of women entrepreneurs. The current study was taken up to investigate the working of twentyseven women entrepreneurs working on micro and small levels, in different areas of Uttar Pradesh (India), who have created employment opportunities for thousands of people living at grass root level and also created new prospects for the rural artisans in their region. The study aimed to explore the various the obstacles faced by the women entrepreneurs working in different areas of Uttar Pradesh (India), analyze the impact of the prevailing constraints and challenges on the progress of these women entrepreneurs, and recommend the aspects that he to be looked into by the policy makers, to address the issues and challenges. It is also anticipated that the findings will bring to light valuable insights, which might be used by the policymakers, organization and institutions who intend to assist more and more entrepreneurs, especially women entrepreneurs, to venture into businesses. The study revealed multifarious constraints and challenges faced by the women during their entrepreneurial journey. In the current study, we have tried to

\footnotetext{
1 Assistant Professor, address: Vineet Khand, Gomti Nagar, Lucknow - 226010, India, phone: +91-522-2394296, 97, fax: +91-522-2394295, e-mail: reena.agarwal@jaipuria.ac.in
} 
classify these constraints into four broad categories: Socio-Cultural Issues; Economic Issues; Psychological Issues and Managerial Issues.

KEY WORDS: cultural constraints, inadequate finance, gender discrimination, risk averse, lack of leadership

\section{Introduction}

Entrepreneurship is a good source of generating economic growth and social development (Venkat Subramaniam, 2003). It is a universally accepted fact, that entrepreneurs are the engine for economic growth. The better we understand the elements of successful entrepreneurship, the superior will be the betterment of society and brighter future (Harold and Loren, 2009). Ever since entrepreneurship was a male-dominated activity, but with the change in time, women also are proving to be inspiring entrepreneurs. Some of the statistics validate that women's participation in economic activities, play a decisive role in the growth and development of many economies across the world (Minniti et al., 2005; Roomi et. al., 2009). In USA, twenty five percent of the total businesses are possessed by women, while in France and Canada one-third and 20\% small businesses are owned and operated by women entrepreneurs respectively. In Asia, women comprise forty percent of the total workforce, whereas in China womenfolk are leading men by at least two-fold and comparable trend has been observed in Japan as well (Rao et al, 2011).

According to Brush and Cooper (2012) women entrepreneurship is growing very fast around the world. Women entrepreneurs make noteworthy contributions in terms of generating employment opportunities and creating wealth in all economies (Acs and Audretsche, 1990; Reynolds et al., 2002; Brush and Cooper, 2012). In spite of the obvious benefits that women entrepreneurs offer to an economy and country as a whole, the actual potential of female entrepreneurship has yet not been unconcealed. Women entrepreneurs across the world still continue to encounter innumerable constraints and challenges which limit their performance and profitability.

\section{Objective of Study}

Women entrepreneurs are yet to accomplish their full potential in men controlled business world. The current study was taken up to investigate the 
working of twenty-seven women entrepreneurs working on micro and small levels, in different areas of Uttar Pradesh (India), who have created employment opportunities for thousands of people living at grass root level and also created new prospects for the rural artisans in their region. The study aims to: (1) explore the various the obstacles faced by the women entrepreneurs working in different areas of Uttar Pradesh, the most populous state, in the Republic of India, (2) analyze the impact of the prevailing constraints and challenges on the progress of these women entrepreneurs, and (3) recommend the aspects that he to be looked into by the policy makers, to address the issues and challenges.

\section{Research Methodology}

An empirical research was conducted to find out the challenges and constraints encountered by the women entrepreneurs in the emerging economy (Pavlovic, Ljumovic, 2016). According to Dörnyei, (2007), the most popular method of collecting the qualitative data used by researchers is through interviews and questionnaires. Interviews - in comparison to questionnaires- are more powerful in drawing descriptive data and it allows researchers to explore and examine people's views in greater depth (Kvale, 1996; 2003). Cohen et al (2007) added that interviewing is "a valuable method for exploring the construction and negotiation of meanings in a natural setting". Initially, I briefly reviewed the literature concerning the use of interviews, the interviews' types and understood the used of this method in eliciting vital insights. Then the research methods that I decided to use were personal interviews and group interview. A detailed schedule with open ended questions was prepared after gathering insights from the available.

Convenience sampling was used, it was decided to interact with women entrepreneurs in the state of Uttar Pradesh. Identified twenty-seven women entrepreneurs, who were involved in the manufacturing of jute bags, other jute products, home-made traditional snacks, pickles, spices, embroidered clothes, bedsheets, table-cloth, artificial jewelry, handicrafts and pottery items in Uttar Pradesh (India), the most populous state, in the Republic of India. These entrepreneurs have successfully provided employment to thousands of illiterates, un-skilled and semi-skilled people, living at the grass root level in their local community.

Personal interviews of all the twenty-seven entrepreneurs were conducted. The workforce was also interviewed to understand the basic busi- 
ness operations and the hurdle faced by them in their day to day operations. The research questions that were used to extract vital insights include the following:

1. Did you face any family, societal, cultural constraints in operating your own enterprise?

2. Did you face any problem in arranging necessary funds for your business enterprise?

3. What is your education level?

4. Did you take any formal training before starting your venture?

5. Did you have market exposure prior to initiating your venture?

6. How do you keep yourself updated about the fast moving changes?

The information collected from series of interviews helped in inferring valuable insights. The secondary data was collected from online journals, reports of government departments and research reports of private agencies, surveys, and other online resources.

\section{Implication of Research}

It is expected that the findings of this study will draw the attention of the, towards the obstacles that hamper the progress and advancement of the businesses owned and managed by women entrepreneurs. It is also anticipated that the findings will bring to light valuable insights, which might be used by the policymakers, to address the ongoing problems and create a more enabling environment for the women entrepreneurs. The output of this research is likely to benefit women entrepreneurs who intend to initiate and develop their businesses and also to the organization who intend to support entrepreneurs, especially women entrepreneurs, to venture into businesses.

\section{Review of the Literature}

Women entrepreneurs in contrast their male colleagues are usually subject to numerous obstacles which render the business environment unconducive to operate. The passages that follow elaborate on the constraints and challenges face by the women entrepreneurs across the world: 


\section{Cultural Constraints}

Traditions and conventions pose hurdles in the smooth operation of business, by women in the society. The social belief holds that males are the bread winners in families. According to Roomi and Parrot (2008) women are majorly compelled to take care of home (Roomi and Parrot, 2008). And if a woman exhibited her desires for entrepreneurial pursuit, it was assumed that she wanted to undertake the leadership role in family. A study by Barwa (2003) disclosed that women confront added handicap owing to the prevalent societal and traditional gender-based inequities and prejudices.

Although women have been making efforts to attain equality with their male counterparts, in areas like workplace and education, their role in family, in terms of homemaking and parenting, remains somewhat unmoved (Winn, 2004; McGowan et al., 2012). According to Calas and Smircich (1992) and Morris et. al., (2006), ethnically enforced outlook toward femininity acts as blockades to females attaining greater economic benefits and recognition in the corporate world. The key factor that confines women from business are biases based on gender and lack of support from community (Afza, Hassan and Rashid, 2010).

\section{Inadequate Finance}

A variety of studies found that often lack of adequate funds was the major reason for a women entrepreneur to discontinue their business rather than failure in business (Boden and Nucci, 2000; Du Rietz and Henrekson, 2000; Karim, 2001; Watson, 2003). The women entrepreneurs did not have access to credit, from formal institutions, due to: lack of formal education, limited ownership of property, lack of negotiation skills and limited social mobility (Ayadurai, 1987). United Nations Industrial Development Organisation (UNIDO, 2003) report suggested that though it is a proven fact that loan repayment ratio of women is far better than that of men still, women confronted problems in arranging funds frequently because of the biased approach of the finance institution. Starcher (1996) submitted that women entrepreneurs in emerging countries had little availability of funds, due to their poor financial position and their inability to provide tangibles securities.

According to Indarti and Langenberg (2005), banks often overstated the probability of default of women entrepreneurs, and therefore levied whimsically high collateral requirements, which resulted in limited credit. A num- 
ber of studies displayed that the poor access to capital and financial restraints were the main obstacles to women entrepreneurship and success in developing economies (Marsden, 1992; Meier and Pilgrim, 1994; Steel, 1994). The findings of Brush et. al., (2004) and Fielden et al., (2003), the opinion about women entrepreneur that they do not have desire for growth, lack leadership and managerial acumen, seemed to inhibit availability of credit to them. Hisrich and Brush (1984), Karim (2001) and Ndwandwe (1998) noticed that funding problems encountered by women entrepreneur resulted in limited prospects to graduate into larger organization. Verheul and Thurik (2001) and Kuada (2009) suggested, women entrepreneurs had little knowledge of financial management.

\section{Lack of Information}

Access to right information is equally vital to operate business unit. Singh and Krishna (1994), in the study, stated that keenness to seek vital information is one of the necessary traits to become successful entrepreneur. Access to new information is crucial for commencement, existence and progress of business enterprises (Mead and Liedholm, 1998; Kristiansen, 2002; Swierczek and Ha, 2003; Duh, 2003). One of the key limitation of women entrepreneur is limited access to vital information, (Afza, Hassan and Rashid, 2010).

\section{Poor Networking}

Networks represent a means for minimizing the threats and operating costs, improving reach to unique business ideas and funds (Aldrich and Zimmer, 1986; Indarti and Langenberg, 2005). Kristiansen (2003) found that social network has significant relationship with business adaptability. Through networking entrepreneurs can get counsel (Bruderl and Preisendorfer, 1998) cooperation (Greve and Salaff, 2003), obtain implicit understanding (Linehan and Scullion, 2008), form tactical coalitions (Tonoyan et. al., 2010), come across new business prospects (Farr-Wharton and Brunetto, 2007), and attain reliability and acceptability for them and their enterprise (Carter and Shaw 2006). It has been noticed that women entrepreneurs were poor in developing business networks, effective networking can offer significant benefits to the women entrepreneurs (Linehan and Scullion, 2008) through comparative advantage in business (Miller et. al., 2007). 
It was observed that women had inhibition in sharing their business ideas and secrets with others as the apprehension was that it might lead to creating competitors (Knouse and Webb, 2001; McGowan et al., 2012). Women entrepreneurs who intermingle with business associates are perceived negatively by the society (Ayadurai, 1987). Knouse and Webb, 2001; McGowan et al., 2012 found that marginalization from male subjugated networks have proved to be chief barrier to the advancement of women entrepreneurs in the business world. Tonge (2008) said women lack confidence, this makes hesitant towards interacting with male members and making new linkages (McGowan and Hampton, 2006).

\section{Duty towards Family}

Fasci and Valdez (1998) and Birley (1989) stated that numerous family duties leave less time with women entrepreneurs for their business endeavours (Rao, Rao and Suri Ganesh, 2011; McGowan et. al., 2012). Having responsibility towards home, children, elderly dependent, and women fail to devote majority of energy and time in business (Starcher, 1996). Stoner et al. (1990), Maysami et al. (1999) and Karim (2001) observed women stressed out because of dual responsibility of taking care family and handling business enterprise. Women`s approachability to the vital capabilities, talents and know-hows for enterprise is unfavorably influenced by limitations on their movement, their duties towards household-businesscommunity, due to which they fail to pursue their personal likings and benefit from their abilities (Ayadurai, 1987; Longstreth et. al., 1987; McGowan et. al., 2012; Morris et. al., 2006 and Stoner et. al., 1990).

\section{Low Education and Skill}

Previous researchers found that the performance of entrepreneurs what greatly affected by their abilities, separation and business understanding (Cheston \& Kuhn, 2002; Akanji, 2006; Kuzilwa, 2005). People who are better educated, have necessary skill-set, have exposure and are good at networking are able to exploit the entrepreneurial opportunities (Shane, 2003). In developed nations as well as developing nations several women entrepreneurs are short of necessary educational base and required training (Ibru, 2009; Afza, Hassan and Rashid, 2010). Hadary (2010) argues that time constraint resulting in low education, lack of training and inexperience reduces the chances of success among women entrepreneurs. 
Inadequate business understanding and lack of managerial acumen resulted in inefficient productivity and poor competitiveness among the women entrepreneurs. Because of lack of technical expertise, self-reliance, strong singular participation and the readiness to take risks, women often were inept to institute and withstand success in venture (Ayadurai, 1987). Richardson et. al., (2004) and Adoram (2011) revealed that numerous women entrepreneurs sensed that they lack capabilities, talents and proficiency in operating venture profitably, majorly due to lack of practical exposure to the business world. UNIDO Document, (2003), emphasized the need for training and advisory services for women entrepreneurs to update their technical and managerial abilities, thus improving productivity and profitability.

\section{Low Risk-taking Ability}

According to Yordanova (2011) risk taking ability has significantly influences entrepreneur's readiness to tap the tangible, intangible and financial resources required for an organization's growth. Low education results in low self-reliance and low self-sufficiency among the women entrepreneur to participate in venture that involves continual risk-taking. Both continuing business activities and generating of surpluses, entail high risk-taking ability and attitude. As cited by Robinson (2007) women were extra risk averse (Anna et al., 1999; Cooper, 1993; Cliff, 1998; Yordanova, 2011; Adoram, 2011) and were less concerned about monetary gain (Rosa et. al., 1996; Brush, 1992). Women entrepreneurs cited that could not assume huge risk because of the limitations as women and their background thus they avoid risky ventures (Morris et. al., 2006).

\section{Poor Access to Markets}

Women were not capable to market services and goods tactically, because they frequently lacked access to knowledge, expertise, contacts, exposure and training. In addition, women entrepreneurs lacked exposure to international market, could not bear the cost of creating linkages in overseas markets were big deterrent for women-owned businesses (Hookimsing \& Essoo, 2003). Market liberalization has amplified the competition and that requires prompt response to market demands, enterprises encounter extensive competition from multinational companies and low-cost producers, and therefore women entrepreneurs need to upgrade skills, technology and professional competence to remain viable (Nayyar et. al., 2007). Marketing 
requires means confidence in dealing with outside world, and the social conditions have discouraged the development of both in women (Starcher, 1996).

\section{Gender Discrimination}

Coleman (2000) revealed that men were more engaged in ventures in comparison to women, as customary duty of women, could dissuade them to take up the opportunity to accumulate start-up capital. And that women entrepreneurs were under-served by financial organizations. Hafizullah et al (2012) stressed domination of men in society, created difficulties for women entrepreneurs. Besides the socio cultural and religious elements women also faced trials of on account of gender biases (Ahmad, 2011; Afza, Hassan and Rashid, 2010).

\section{Lack of Leadership and Management Skills}

Findings of research that displayed that inadequate leadership, insufficient planning and inefficient allocation finances were a few of the problems which women entrepreneurs face win operating their venture (Palaniappan, Ramgopal and Mani, 2012). The other key restraints included lack of trust in one`s abilities and poor access to resources (Afza, Hassan and Rashid, 2010). Mayoux (2001) noted that business women lacked aptitude to exploit existing prospects and that lead to failure in business (Kantor, 1999).

According to Mayoux (2001) and United Nations (2006) the constraints faced by women entrepreneurs were: inefficient financial management, issues of liquidity, naivety, inability in management, inadequate record keeping, problem in sales, marketing and staffing, difficulties in dealing with workforce, limited networking (Coleman, 2000; Parihar and Singh, 2006).

\section{Findings \& Discussion}

The interaction with the women entrepreneurs and the discussions with their teams revealed that though the society and economy are undoing huge changes still the women entrepreneurs face innumerous constraints related to accessibility of funds, struggles between family and work, networking challenges, lack of knowledge and managerial abilities. The figure 1 on 'Challenges Faced by Women Entrepreneurs and the Way Forward' clearly portrays the multifarious constraints and challenges faced by the women 
during their entrepreneurial journey. In the current study, we have tried to classify these constraints into four broad categories: Socio-Cultural Issues; Economic Issues; Psychological Issues and Managerial Issues.

A. Socio-Cultural Issues: Women entrepreneurs shared that they encounter cultural constraints and gender discrimination. They told that their duty towards their families often did not let them concentrate fully in their ventures. Lack of family support was one of the reasons for the low risktaking ability of the women entrepreneurs and the societal barriers often were the cause for poor networking. This was in concurrence to the earlier research which stated that women confronted added handicap due to the prevalent societal and traditional gender-based inequities and prejudices (Calas and Smircich, 1992; Barwa, 2003; Morris et. al., 2006; Afza, Hassan and Rashid, 2010) and that multiple family duties leave less time with women entrepreneurs for their business endeavours (Fasci and Valdez, 1998; Birley, 1989; Karim, 2001; Morris et. al., 2006; McGowan et. al., 2012).

B. Economic Issues: Issues such as inadequate finance, poor access to markets and lack of information often restrained the growth of women entrepreneurs. It was told that banking institutions hesitated to sanction loans to women entrepreneurs as they doubted their risk-taking ability and their entrepreneurial expertise. Women entrepreneurs also faced difficulties in accessing the markets and keeping themselves updated with the latest developments across the globe. This was in congruence with finding of the previous studies which disclosed that women confronted problems in obtaining credit due to bias and perception of credit agencies (Marsden, 1992; Coleman, 2000; Meier and Pilgrim, 1994; Verheul and Thurik, 2001; Fielden et al., 2003; Steel, 1994; Brush et. al., 2004; Kuada, 2009).

C. Psychological Issues: The research also revealed that low level of education and formal professional training were some of the common reasons for the psychological issues such as lack of confidence and low risktaking ability amongst women entrepreneurs, which adversely affected their performance. This was analogous to the findings of the previous researchers who documented that many women entrepreneurs lacked in education, practical exposure and appropriate training both in advanced and emerging nations which eventually affected the entrepreneur's performance (Richardson et. al., 2004; Ibru, 2009; Afza, Hassan and Rashid, 2010; Hadary, 2010; Adoram 2011) and lack of technical expertise, self-reliance, strong singular participation and the readiness for risk exposure, women often were inept to start and withstand business success (Ayadurai, 1987). 
D. Managerial Issues: The research also disclosed that lack of formal training and practical exposure lead to lack of leadership skills, lack of management skills, lack of information and poor networking amongst women entrepreneurs which resulted into managerial inefficiencies. Findings of research was concurrent to previous disclosures which displayed that the lack of appropriate managerial and leadership skill and financial acumen, women entrepreneurs faced problems during execution of businesses (Coleman, 2000; Parihar and Singh, 2006; Afza, Hassan and Rashid, 2010; Palaniappan, Ramgopal and Mani, 2012) and they were poor in developing business networks and national as well as international linkages (Hookimsing \& Essoo, 2003; Nayyar et. al., 2007; Linehan and Scullion, 2008; Miller et. al., 2007).

Figure 1: Challenges Faced by Women Entrepreneurs and the Way Forward

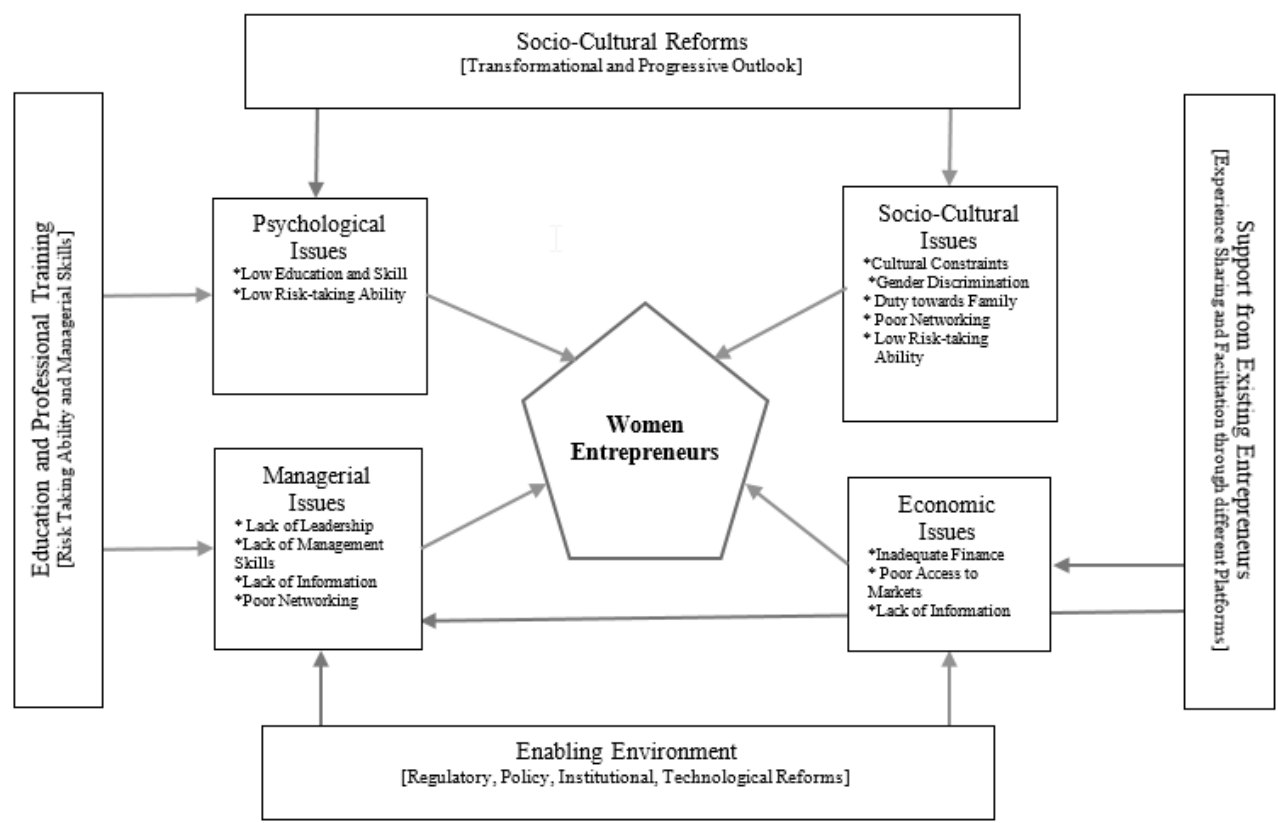

The valuable insights drawn from the research suggest that the ongoing issues and problems should be tackled in four different fronts (Figure 1):

A. Socio - Cultural Reforms: Socio - cultural reforms in the form of elimination of gender-based inequities and prejudices, reform of outdated ethical outlook, building progressive family policies, inspiring strong com- 
munal support need to be initiated to support women`s participation in economic growth through entrepreneurship. A societal revolution can be brought about with a large number of women stepping frontward in the arena of entrepreneurship, which can increase their financial liberation and poise and open up new horizons for them. Thus, the socio - cultural reforms would help in addressing the societal and cultural constraints and psychological issues confronted by women entrepreneurs.

B. Education and Professional Training: The policy framework and institutional infra-structure for developing entrepreneurial abilities, imparting vocation education and training would broaden the horizon for financial enablement for women. It is desirable that the state and non-state institutions and organizations individually and jointly need to develop entrepreneurship development and training programs for the women entrepreneurs to build desired competencies amongst the women entrepreneurs and equip them appropriately to combat competition, both locally and in overseas markets. Thus, the formal education and professional training on one hand would minimize the psychological inhibitions and on the other would resolve the managerial challenges encountered by women entrepreneurs.

C. Creating an Enabling Environment: It is also necessary that there should be increase in the momentum of the ongoing regulatory, policy, institutional and technological reforms. Unbiased approach towards women, simplification of the procedures and processes, making the systems transparent and fair, would boost an enabling environment, empower the women entrepreneurs, and this would subsequently lift growth in economy. Preventive vigilance by the regulators can further improve the system of governance and can help in ensuring efficiency and effectiveness. The government machinery can also think of helping the women entrepreneurs in gaining access to international markets. Thus, the enabling environment would help in addressing the economic constraints and also to some extent the managerial challenges faced by women entrepreneurs.

D. Support from Existing Entrepreneurs: It is also necessary that established entrepreneurs should create new platforms for: (1) facilitating networking, (2) assisting in market outreach (both domestic and international markets), (3) gaining from new financing options, (4) sharing market intelligence, (5) providing hand holding support and (6) assisting in trouble shooting, to help women entrepreneurs to guarantee that their enterprises grow smoothly. Thus, support provided by the existing entrepreneurs can be 
instrumental in tackling economic constraints as well as managerial challenges confronted by women entrepreneurs.

\section{Conclusion}

In the history of humankind, woman has been as important as man and the status, employment and work performed by women in society are the indicator of a nation's overall progress. Without the participation of women in national activities, the social, economic or political progress of a country will be stagnated. In the wake of economic liberalization and globalization, women entrepreneurship is gaining importance. There are no bigger initiative nations can take to speed up the jump of economic growth, than to boost more and more women to take part in the entrepreneurial activity.

\section{Limitations and Future Research Agenda}

The current research was limited to investigating the women entrepreneurs, in the state of Uttar Pradesh (India). A similar study can be replicated in the other states of the country to get a holistic perspective. Further research can be taken up to understand how cross-cultural trade affects women entrepreneurs across the world, how women entrepreneurs are managing their survival and growth in today`s era of globalization. There is also a need to use a mix of quantitative and qualitative techniques to reach realistic conclusions.

\section{References}

[1] Acs, Z. and Audretsch, D. (1990). "Innovation and Small Firms", The MIT Press, Cambridge, MA.

[2] Adoram, G. (2011), "Gender differences and their impact on Entrepreneurial Ventures", Advances in Management, Vol 4 (2), pp. 13-18.

[3] Afza, T., Hassan, M. and Rashid, M.A., (2010). "Enterprising Behavior of Enterprise-less Rural Women Entrepreneurs of Khyber Pakhtunkhawa of Pakistan", European Journal of Social Sciences, Vol. 18, No. 1, pp. 109-119.

[4] Ahmad, S.Z., (2011). "Businesswomen in the kingdom of Saudi Arabia: Characteristics, Growth patterns and Progression in Regional Context", Equality, diversity and Inclusion: an International journal, Vol. 30, No. 7, pp. 610-614. 
[5] Akanji, O. O., (2006). "Microfinance as a Strategy for Poverty Reduction". Central Bank of Nigeria Economic and Financial Review, 39 (4).

[6] Aldrich, H., \& Zimmer, C., (1986). "Entrepreneurship through social network". In D. L. Sexton \& R. W. Smilor (Eds.), The Art and Science of Entrepreneurship (pp. 3-25). Cambridge: Ballinger Publishing.

[7] Anna, A.L., Chandler, G.N., Jansen, E. and Mero, N.P., (1999). "Women Business Owners in Traditional and Non Traditional Industries", Journal of Business Venturing, 15 (3), pp. 279-303.

[8] Ayadurai, D., (1987). "The Employer, the Employee and the Law in Malaysia", Butterworths: London.

[9] Barwa, S.D., (2003). "Impact of Start Your Business (SYB) Training on Women Entrepreneurs" Working Paper Series No. 1, ILO Office in Vietnam.

[10] Birley, A.S., (1989). "Women and Business Ownership: Entrepreneurs in Dallas", Routledge: London.

[11] Boden, B.J. and Nucci, A.R., (2000). "On the survival prospects of men's and women's new business ventures", Journal of Business Venturing, 15(4), pp.347-362.

[12] Bruderl J, Preisendorfer P and Ziegler R., (1998). "Survival chances of newly founded business organizations", American Sociological Review 57: 227-242.

[13] Brush, C.G., (1992). "Research of women business owners: Past trends, a new perspective, future directions", Entrepreneurship Theory and Practice, 16(4), pp. 5-30.

[14] Brush, C.G. and Cooper S., (2012). "Female entrepreneurship and Economic Development, An International Perspective", Entrepreneurship and Regional Development: An International Journal, 24: Vol 1-2, pp.1-6.

[15] Brush, C., Carter, N., Gatewood, E., Greene, P. and Hart, M., (2004). "Clearing the Hurdles: Women Building High Growth Businesses", Financial Times-Prentice-Hall, London.

[16] Calás, M., \& Smircich, L., (1992). "Using the "F" Word: Feminist Theories and the Social Consequences of Organizational Research". In A. Mills \& P. Tancred (Eds.), Gendering Organizational Theory. Newbury Park: Sage.

[17] Carter, S. and Shaw, E., (2006). "Women's Business Ownership: Recent research and policy developments". Small Business Service: London.

[18] Cheston, S. \& Kuhn, L., (2002). "Empowering Women through Microfinance. A Case Study of Sinapi Aba Trust, Ghana". USA: Opportunity International.

[19] Cliff, J.E., (1998). "Does one size fit all? Exploring the relationship between attitudes towards growth, gender, and business size". Journal of Business Venturing, 13, 523-542.

[20] Cohen, L., Manion, L., \& Morison, K. (2007). Research Methods in Education. (6th Ed.). London: Routledge. 
[21] Coleman, S., (2000). "Access to Capital and Terms of Credit: A Comparison of Men- And Women-Owned Small Businesses".

[22] Cooper, A.C., (1993), "Challenges in predicting new firm performance", Journal of Business Venturing, 8(3), pp. 241-253.

[23] Dörnyei, Z. (2007). Research Methods in Applied Linguistics: Quantitative Qualitative, and Mixed Methodologies. Oxford: Oxford University Press.

[24] Duh, M., (2003). "Family enterprises as an important factor of the economic development: the case of Slovenia". Journal of Enterprising Culture, 11(2), 111-130.

[25] Du Rietz, A. and Henrekson M., (2000). "Testing the female underperformance hypothesis", Small Business Economics, 14(1), pp. 1-10.

[26] Fasci, M.A. and Valdez, J., (1998). "A performance contrast of male- and female-owned small accounting practices”, Journal of Small business Management, 36(3), pp. 1-7.

[27] Farr-Wharton, R. and Brunetto, Y., (2007). "Women Entrepreneurs, Opportunity Recognition and Government-Sponsored Business Networks: A Social Capital Perspective", Women in Management Review, Vol. 22, No. 3, pp. 187-207.

[28] Fielden SL, Davidson MJ, Dawe AJ, Makin PJ (2003). "Factors inhibiting the economic growth of female-owned small businesses in North West England", J. Small Business Enterprise Development 10(2): 152-66.

[29] Greve, A. and Salaff, J.W., (2003). "Social networks and entrepreneurship", Entrepreneurship Theory and Practice, Vol. 28 No. 1, pp. 1-22.

[30] Hadary, S., (2010). "Launching women-owned businesses onto a high growth trajectory". National Women's Business Council. Retrieved from http://www.nwbc.gov/.

[31] Hafizullah, Ahmed, Z.M., Manzoor, S.R., Hussain, M. and Farooq, M.A., (2012). 'Problems faced by Women entrepreneurs in Kohat city of Khyber Pakhtunkhawa Pakistan', International Journal of Human Resource Studies, Vol. 2, No. 1.

[32] Harold O. Fried and Loren W. Tauer, (2009). "Understanding the Entrepreneur: an index of entrepreneurial success". Frontiers of Entrepreneurship Research, Volume 29, Issue 5, Article 7.

[33] Hisrich, R., and Brush, C., (1984). "The Woman Entrepreneur: Management skill and Business Problems:' Journal of Small Business Management 22 (1): 30-37.

[34] Hookoomsing and Essoo (2003). Seed Working Paper No. 58, "Promoting Female Entrepreneurship In Mauritius: Strategies In Training And Development". International Labour Office, Geneva.

[35] Ibru, C., (2009). "Growing Microfinance through New Technologies". Federal University of Technology, Akure, Nigeria. 
[36] Indarti, N. and Langenberg M., (2005), "Small and Medium Enterprises Development Center (SMEDC)", Gadjah Mada University, Yogyakarta, Indonesia.

[37] Kantor, P., (1999). Promoting women s entrepreneurship development based on good practice programmes: some experiences form the North to South, (An ILO Working Paper on Series of Women s Entrepreneurship Development and Gender in Enterprises WEDGE Working) No. 9.

[38] Karim, N.A., (2001). "Jobs, Gender and Small Enterprises in Bangladesh: Factors Affecting Women Entrepreneurs in Small and Cottage Industries in Bangladesh", SEED Working Paper No. 14, International Labour Office, Geneva.

[39] Knouse, S. B., and Webb, S. C., (2001). 'Virtual networking for women and minorities', Career Development International, Vol 6, No 4, pp 226229.

[40] Kristiansen, S., (2002). "Competition and Knowledge in Javanese Rural Business", Singapore Journal of Tropical Geography, 23 (1), 52-70.

[41] Kristiansen, S. (2003). "Social network and business success: the role of sub-cultures in an African context". American Journal of Economics and Sociology.

[42] Kuada, J. (2009), “Gender, Social Networks, and Entrepreneurship in Ghana”, Journal of African Business, Vol 10, pp. 85-103.

[43] Kuzilwa, J., (2005). "The Role of Credit for Small Business Success: A Study of the National Entrepreneurship Development Fund in Tanzania". The Journal of Entrepreneurship, 14 (2), 131-161.

[44] Kvale, S. (1996). InterViews: An introduction to qualitative research interviewing. Thousand Oaks, CA: Sage.

[45] Kvale, S. (2003). The psychoanalytic interview as inspiration for qualitative research. In P. M. Camic, J. E. Rhodes, \& L. Yardley (Eds.), Qualitative research in psychology. Washington, USA: American Psychological Association, pp. 275- 297.

[46] Linehan, M. and Scullion, H., (2008). "The development of female global managers: the role of mentoring and networking", Journal of Business Ethics, Vol. 83, pp. 29-40.

[47] Longstreth, M., Stafford, K., \& Mauldin, T., (1987). "Self-employed women and their families: Time use and socioeconomic characteristics". Journal of Small Business Management, 25(3), 30- 37.

[48] Marsden, K., (1992). "African entrepreneurs pioneers of development". Small Enterprise Development, 3(2): 15-25.

[49] Mayoux, Linda, (2001). "Jobs, Gender and Small Enterprises: Getting the Policy Environment Right". SEED Working Paper No. 15, International Labour Office, Geneva. 
[50] Maysami Cooper et. al., (1999). "Female Business Owners in Singapore and Elsewhere: A Review of Studies", Journal of Small Business Management. 37 (1),

[51] Meier R, Pilgrim M., (1994). "Policy-induced constraints on small enterprise development in Asian countries". Small Enterprise Development 5(2): 32-38.

[52] McGowan, P. and Hampton, A., (2006). "An exploration of the Networking Practices of Female Entrepreneurs", Chapter 6 in C. Henry, N. Carter, K. Johnston and B. O' Cinneide (Eds.) Promoting Female Entrepreneurship: Implications for Education, Training and Policy', London: Routledge.

[53] McGowan, P., Redeker, C.L., Cooper, S.Y. and Greenan, K., (2012). "Female entrepreneurship and the management of business and domestic roles: Motivations, expectations and realities”, Entrepreneurship \& Regional Development: An International Journal, 24:1-2, pp. 53-72.

[54] Mead, Donald and Liedholm, (1998). "The Dynamics of Micro and Small Enterprise in Developing Countries." World Development, Vol. 26 No. 1, 61-74.

[55] Miller, N.J., Besser, T.L. and Riibe, J.V., (2007). "Do strategic business networks benefit male-and female-owned small community businesses", Journal of Small Business Strategy, Vol. 17 No. 2, pp. 53-74.

[56] Minniti, M., Arenius, P. and Langowitz, N., (2005). "2004 Global Entrepreneurship Monitor Special Topic Report: Women and Entrepreneurship", Center for Women's Leadership at Babson College, Babson Park, MA.

[57] Morris, M.H., Miyasaki, N.N., Watters, C.E. and Coombes, S.M., (2006). "The Dilemma of growth, Understanding Venture Size choices of women entrepreneurs", Journal of Small Business Management, 44(2), pp. 221-244.

[58] Nayyar P., Sharma A., Kishtwaria J., Rana A., Vyas N., (2007). "Causes and Constraints Faced by Women entrepreneurs in Entrepreneurial Process", Journal of Social Sciences, Vol.14, No.2, pp. 99-102.

[59] Ndwandwe, M., (1998). "Entrepreneurship in a developing economy: South African Case". 2nd Edition, B Publications: Windhoek.

[60] Parihar, C. and Singh, G., (2006). "The Promotion of Women Entrepreneurs and Leadership in India and beyond". Elsevier: New Delhi

[61] Pavlovic, D. and Ljumovic, I. (2016). "Prospects and Challenges for Female Leaders from the Balkans “,Journal of Women's Entrepreneurship and Education, vol 1(2), pp 58-75.

[62] Rao, S.T., Rao, G.T. and Suri Ganesh, M.P., (2011). "Women Entrepreneurship in India (A case study in Andhra Pradesh", The Journal of Commerce, 3(3), pp 34-47.

[63] Reynolds, P. et al., (2002). "The entrepreneur next door: Characteristics of individuals starting companies in America". The Panel Study of Entrepre- 
neurial Dynamics: The Ewing Marion Kauffman Foundation, Executive Summary.

[64] Richardson, K.A., Goldstein, J.A., Allen, P.M. and Snowden, D., (2004). "Emergency: Complexity and Organisation". 2nd Edition. Volume 2.ISCE Publishing. London.

[65] Robinson, A., (2007). "Business failure Rates, a look at sex and location", Academy of Entrepreneurial Journal, Volume 13, No1, pg 45-56.

[66] Rosa, P., Carter, S. and Hamilton, D., (1996). "Gender as a determinant of small business performance: insights from a British study", Small Business Economics, No. 8, pp. 463-78.

[67] Roomi, A, M., Harrison, P., Beaumont-Kerridge, J., (2009). "Womenowned small and medium enterprises in England: Analysis of factors influencing the growth process", Journal of Small Business and Enterprise Development, Vol 16, no.2, pp.270-288.

[68] Roomi, M.A. and Parrot, G., (2008). "Barriers to Development and Progression of Women Entrepreneurs in Pakistan", Journal of Entrepreneurship, Vol. 17, No. 1, May, pp. 59-72.

[69] Singh, K. A., \& Krishna, K. V. S. M., (1994). “Agricultural Entrepreneurship: The Concept and Evidence". Journal of Entrepreneurship, 3(1), 97111.

[70] Shane, S., (2003). "A general theory of entrepreneurship: The individualopportunity nexus". UK: Edward Elgar.

[71] Starcher, D.C., (1996). "Women entrepreneurs: Catalysts for transformation", available at http://www.ebbbf.org/woman.htm, (Retrieved 6 July 2012).

[72] Steel W., (1994). "Changing the institutional and policy environment for small enterprise development in Africa". Small Enterprise Development 5(2): 4-9.

[73] Stoner, Charles R., Hartman, Richard I., (1990). "Work-Home Role Conflict in Female Owners of Small Businesses: An Exploratory Study”, Journal of Small Business Management, Vol 28 (1), pp 27-53.

[74] Swierczek, F. W., \& Ha, T. T., (2003). "Entrepreneurial orientation, uncertainty avoidance and firm performance: an analysis of Thai and Vietnamese SMEs". International Journal of Entrepreneurship and Innovation, 4(1), 4658.

[75] Tonge, J., (2008). "Barriers to networking for women in a UK professional service", Gender in Management: An International Journal, Vol. 23 No. 7, pp. 484-505.

[76] Tonoyan, V., Budig, M., \& Strohmeyer, R., (2010). "Exploring the heterogeneity of women's entrepreneurship: The impact of family structure and family policies in the Europe and the US”. In C.G. Brush, A. de Bruin, E.J. 
Gatewood, \& C. Henry (Eds.), Women entrepreneurs and the global environment for growth (pp. 137-159). Cheltenham: Edward Elgar.

[77] United Nations Industrial Development Organization, Vienna, (2003). "Developing Rural and Women Entrepreneurship".

[78] United Nation, (2006). "Entrepreneurship and e-Business Development for Women”. United Nations Publications, United Nations Publication. Pp. 1-14.

[79] Venkat Subramaniam, S., (2003). "Economic Development through Entrepreneurship in India". (M.Sc. paper), available at http://dspace.mit.edu/bitstream/handle/1721.1/29720/54038286.pdf

[80] Verheul, I. and Thurik, A. R., (2001). "Start-up capital: does gender matter?" Small Business Economics.

[81] Yordanova, D.I., (2011). "The effects of Gender on Entrepreneurship in Bulgaria: An Empirical Study", International Journal of Management, Vol. 28 No1, Part 2.

[82] Watson, J., (2003). "Failure rates for female-controlled businesses: Are they any different"? Journal of Small Business Management, 41(3), pp. 262-277.

[83] Winn, J., (2004). "Entrepreneurship: not an easy pathway to top management for women". Women in Management Review. Vol 19. No 3. pp 145153.

Article history: $\quad$ Received: 3 October, 2018

Accepted: 28 November, 2018 